\title{
Adaptive behavior of Scotocryptus melitophilus Reitter (Coleoptera, Leiodidae) to live with its host Melipona quadrifasciata Lepeletier (Hymenoptera, Apidae)
}

\author{
José Maurício Dias Bezerra ${ }^{1}$ \\ Rui Carlos Peruquetti ${ }^{2}$ \\ Warwick Estevam Kerr ${ }^{3}$
}

\begin{abstract}
Forty six beetles Scotocryptus melitophilus Reitter, 1881 collected in a nest of Melipona quadrifasciata Lepeletier, 1836 were studied. All beetles were put together in a large petri dish with 14 males, 14 virgin queens and 14 workers of $M$. quadrifasciata, which was not aggressive towards the $S$. melitophilus and flew with 3 to 10 beetles attached to them. When groups of 20 workers, 20 males and 20 virgin queens were put separately in three petri dishes, the workers become attractive to beetles after they were seven days old, while the males after the 19 days old. Only one virgin queen five days old attracted one beetle. The anatomic parts of the workers bees more attractive to the beetles when smeared to a filter paper were the head $(32 \%)$, abdomen (29\%) and legs (29\%). The part of the workers bees that less attracted the beetles was the thorax (10\%). S. melitophilus, both males and females, are able to distinguish caste, sex and age differences of their host M. quadrifasciata, what can increase the adaptive value of the beetles involved in phoretic behavior.
\end{abstract}

KEY WORDS. Scotocryptus, Melipona, adaptive behavior, phoresy, caste

Comparing ants and termites with social wasps and bees, the number of symbionts is large in the first two groups, whose majority are ground dwellers, and small in the last two groups (WILSON 1971; KISTNER 1982). However, the high-social stingless bees (Apidae, Meliponini) seem to be an exception to this rule. Their nests have many guests as mites, moths, cockroaches, flies, beetles, fungi and bacteria, some of they are obligate symbionts (WASMANN 1904; SALT 1929; NOGUEIRA-NETO 1970; MACHADO 1971; FLETCHMAN \& CAMARGO 1979; APONTE 1996; KERR et al. 1996).

Beetles associated with bees can be classified into two categories: a) parasites and predators and $b$ ) those that use the by-products of the bee's activities, such as honey, pollen, wax, fungi, propolis and garbage (YANEGA \& LESCHER 1994). In the

1) Correspondence address: Departamento de Química e Biologia, Universidade Estadual do Maranhão. Cidade Universitária Paulo VI, Caixa Postal 09, 65000-000 São Luís, Maranhão, Brasil. E-mail: maubez@triang.com.br

2) Laboratório de Genética Bioquímica, Departamento de Genética e Evolução, Universidade Federal de São Carlos. Caixa Postal 676, 13565-905 São Carlos, São Paulo, Brasil.

E-mail: prcp@iris.ufscar.br

3) Departamento de Genética e Bioquímica, Universidade Federal de Uberlândia. Bloco 2E, Sala 20, Campus Umuarama, 38400-902 Uberlândia, Minas Gerais, Brasil.

E-mail: warwick@umuarama.com.br

Revta bras. Zool. 17 (1): 199 - 203, 2000 
latter category is the genus Scotocryptus Girard, 1874. Its four species are all neotropical, as their favorite hosts, stingless bees of the genus Melipona Illiger, 1806. Although, they are occasionally found in association with other meliponine bees (RoUBIK \& WHEELER 1982). The melittophilous Scotocryptus are quite different from the other genera of Leiodidae because they are blind and flightless, lacking membranous wings. Some parts of their body (head, antennae and legs) can be folded and their tibiae rest in grooves on the femora. The median part of each mandible has a deep groove that allows the beetle firmly grasp onto the legs of the bees (ROUBIK \& WHEELER 1982). All these characters facilitate their retention on the host's body, allowing the beetles to be moved phoretically, their only way of dispersing from one host nest to another (WASMANN 1904; NOGUEIRA-NETO 1970; ROUBIK \& WHEELER 1982).

Their larvae also exhibit some adaptations for inquilinism, as dorso-ventral body compression and loss of stemmata (WHEELER 1985). The surface of the larva body is covered with strong setae that can help it not be threw out of the hive by the "garbage bee 2", that is the bee who gets the garbage from the "garbage mound" and takes it to the outside. A stingless bee colony profits from the Scotocryptus population, since it reduces the amount of garbage in the nest (ROUBIK 1989).

This paper adds some behavioral information on Scotocryptus melitophilus Reither, 1881 that suggests these beetles are highest adapted to their hosts, since many of the observed behavior can increase the adaptive value of theses phoretic beetles.

\section{MATERIAL AND METHODS}

Forty six adults of $S$. melitophilus were found in a nest of Melipona quadrifasciata Lepeletier, 1836 located in a branch of a tree (Ficus sp.: Moraceae), $35 \mathrm{~cm}$ in diameter, $5 \mathrm{~m}$ above ground near Viçosa, Minas Gerais $\left(20^{\circ} 45^{\prime} \mathrm{S}\right.$; $\left.42^{\circ} 51^{\prime} \mathrm{W}\right)$.

The beetles were collected and transported to the laboratory of the Apiário Central da Universidade Federal de Viçosa, where they are put in a large petri dish together with some rotten wood, honey, pollen, and garbage, being kept at $28^{\circ} \mathrm{C}$. Moistened cotton maintained humidity high within the petri dish.

In the laboratory three observations were performed with the beetles:

1) In order to know whether phoresy really occur and how many beetles each bee can fly with, the following observation was made. All 46 beetles were put together with 14 males, 14 virgin queens, and 14 workers of M. quadrifasciata in a $15 \mathrm{~cm}$ diameter petri dish. Every time a beetle became attached to a bee, this bee was set free in a room in order to see whether that bee would fly with the beetle attached. The bee was recaptured after 2 minutes. The test was repeated 15 times.

2) To see whether all castes are equally attractive to the beetles, the following experiment was made. Three groups of bees consisting of 20 workers, 20 males and 20 virgin queens, from four different colonies of $M$. quadrifasciata, were formed as soon as they emerged. These bees were considered one day old. They 
were put in a clear glass petri dish $15 \mathrm{~cm}$ in diameter and $2 \mathrm{~cm}$ deep and fed for 30 days. In this time interactions between bees and beetles was promoted separately to each bee group. The interactions were observed for five minutes and every bee had the same opportunity to be reached and grabbed by a beetle. In this period the sex of the beetles (males of the beetles are clearly different from the females due to the presence of patches of yellow hairs on the tarsi of the anterior and median legs) and the frequency of beetles attached to bees of different age was recorded. The beetles were maintained separated from the bees until the moment of the tests, which were made nine times per day (three for workers, three for males and three for queens).

3) In order to find out which part of the bee is more attractive to the beetles, three workers of M. quadrisfasciata were dismembered. Their heads, their thoraces, abdomens and legs were separated macerated and poured onto four filter-papers ( $1 \mathrm{~cm}$ diameter). These papers were put equidistant in a $15 \mathrm{~cm}$ diameter and $2.5 \mathrm{~cm}$ high petri dish. Three beetles were put in the center of the dish and each visit longer than four seconds was considered an attractive behavior.

The beetles were under experiments for 38 days. Voucher specimens of $S$. melitophilus are deposited in the Museu de Entomologia da Universidade Federal de Viçosa and Museu de Zoologia da Universidade de São Paulo.

\section{RESULTS AND DISCUSSION}

Scotocryptus melitophilus grasped with its mandibles the abdomen, legs and, occasionally, wings of $M$. quadrifasciata. The bees do not show aggressiveness towards the beetles. However, after being submitted to 10 minutes of experiments, three workers became aggressive and behave strangely. They began to beat its wings rhythmically, crouch, and subsequently secreted a transparent liquid that in contact with the beetles killed them instantaneously.

The bees flew easily with two beetles, one attached to each corbicula. In one experiment a worker of $M$. quadrifasciata flew with 10 beetles, three in one corbicula and seven in the other, what means $38-48 \mathrm{mg}$ of load (average of $S$. melitophilus weight: $43 \pm 5 \mathrm{mg}, \mathrm{n}=30$ ). The beetles preference for corbicula is understood, since it is the part where the bee apparently has less tendency to try to get rid of extra cargo. When a beetle attaches to the corbicula it folds its legs beneath its body and maintains the antennae exposed.

It was found that only one five day old virgin queen (out of 20) attracted one beetle. All workers were attractive to the beetles after they were seven days old and all males become attractive after they were 19 days old, both until the end of the experiment (30 days).

It was interesting to notice that when the experimenter held a attractive worker or a attractive male with a forceps, this became attractive to the beetles, but if the forceps were used with a non-attractive virgin queen, the beetles paid no attention.

Such observations showed that S. melitophilus, both males and females, are able to distinguish caste, sex and age differences of its host M. quadrifasciata. Thus, 
virgins queens are not quite attractive, workers are very attractive and males are attractive only when they already have left the hive. Since males of M. quadrifasciata are ousted from the hive when they are 10 to 12 days old and for the first three or four days thereafter they are allowed to re-enter the hive, but do not after.

Likely, the eagerness the beetles showed for workers of seven days or more, and not for virgin queens or males (these younger than 19 days old) maximizes their phoretic opportunities. Noteworthy, in M. quadrifasciata, during one year's brood production, approximately, $87 \%$ are workers, $7 \%$ are queens (virgin queens, if the mother colony has a good physogastric queen, are killed in a few hours to 10 days, according to the species) and $6 \%$ are males, therefore S. melitophilus phoresy on virgin queens or males would compromise the adaptive value of the beetles.

The use of host worker and males to phoresy likely confer to the beetle either some guaranty that dispersal will be well succeeded and obligate inbreeding avoided. Because swarming (a possible manner of the some beetles shift to a new host nest) in Melipona bees is done in three steps (KERR 1951; NOGUEIRA-NETO 1954): 1) workers looking for a cavity and sealing it with resins; 2) they transporting food and cerumen to it and forming waxy sheets with their mandibles, 3 ) after this the new nest receive the virgin queen that goes to the nuptial flight. In a reproductive swarm there can be one or two virgins queens, 500 workers and about 50 males (these males come from many hives).

The evident preference for workers and males of M. quadrifasciata by $S$. melitophilus suggests a greater similarity, not only morphological but physiological too, between males and workers than between workers and queens, strengthening the hypothesis of KERR et al. (1978) and KERR \& CUNHA (1990).

Out of 164 visits to the four papers smeared with parts of the worker bodies, 53 were to the head smear, 17 to the thorax, 47 to the abdomen and 47 on the legs. These results do not permit a conclusive discussion, but they show that head, abdomen and legs of $M$. quadrifasciata maybe have some kind of chemical cue to S. melitophilus, but its nature is unknown to us.

ACKNOWLEDGEMENTS. We thank Dr. Lúcio A. O. Campos that allowed this work to be carried out with his colonies of stingless bees in the Universidade Federal de Viçosa. Dra. Cleide Costa (Museu de Zoologia, Universidade Federal de São Paulo) helped in identifying the beetles. Dr. C.D. Michener, Dr. D.W. Roubik and two anonymous reviewers gave us competent suggestions. This work was supported by Universidade Federal de Viçosa and grants of Conselho Nacional de Desenvolvimento Científico e Tecnológico ( $\mathrm{CNPq})$ and Fundação de Apoio à Pesquisa de Minas Gerais (FAPEMIG). The first author had a fellowship of Fundação de Apoio à Pesquisa do Estado do Maranhão (FAPEMA).

\section{REFERENCES}

APONTE, O.I.C. 1996. Arthropodes associated with colonies of stingless bees (Apidae: Meliponinae). Pegone 4: 3-6.

Flechtmann, C.H.W. \& C.A. Camargo. 1979. Acari associated with stingless bees (Meliponinae, Hymenoptera) from Brazil, p. 315-319. In: Hungarian Academy of Sciences (Ed.). Proc. $4^{\text {th }}$ Internat. Congr. Acarol. (1974), 353p. 
KERR, W.E. 1951. Bases para estudo da genética de populações dos Hymenoptera em geral e dos Apinae sociais em particular. Anais ESALQ-USP 8: 219-354.

KeRR, W.E. \& R.A. CunHA. 1990. Sex determination in bees. XXVI. Masculinism of workers in the Apidae. Braz. Journ. Genetics 13: 479-489.

KerR W.E; R.A. Cunha \& J.F. PISANI. 1978. Genética da determinação do sexo em abelhas. XII. Aplicação de métodos numéricos para agrupar sexo e casta de Melipona quadrifasciata anthidioides Lep. (Apidae). Rev. Brasil. Biol. 38: 391-394.

Kerr, W.E.; G.A. Carvalho \& V.A. Nascimento. 1996. Abelha Uruçu: biologia, manejo e conservação. Fundação Acangaú, Belo Horizonte, 143p.

Kistner, D.H. 1982. Social insects bestiary, p. 1-244. In: H.R. HeRmann (Ed.). Social Insects. New York, Academic Press, 437p.

MaCHADO, J.O. 1971. Simbiose entre abelhas sociais brasileiras (Meliponinae, Apidae) e uma espécie de bactéria. Ciência e Cultura 23 (5): 625-633.

NogueiRA-Neto, P. 1954. Notas bionômicas sobre meliponídeos (Hymenoptera, Apoidea). III. Sobre a enxameagem. Arqs Mus. Nac. Rio Janeiro 42: 419-452.

. 1970. A criação de abelhas indígenas sem ferrão (Meliponinae). Chácaras e Quintais, São Paulo, Brazil, $2^{\mathrm{a}}$ ed., $365 \mathrm{p}$.

ROUBIK, D.W. \& Q.D. WeELER. 1982. Flightless beetles and stingless bees: phoresy of scotocryptine beetle (Leiodidae) on their meliponine host (Apidae). Jour. Kansas Entomol. Soc. 55: 125-135.

ROUBIK, W.D. 1989. Ecology and natural history of tropical bees. Massachussetts, Harvard Univ. Press, 514p.

SALT, G. 1929. A contribuition to the ethology of the Meliponinae. Trans. Ent. Soc. London 77: 431-470.

WASMANN, E. 1904. Contribuição para o estudo dos hóspedes de abelhas brasileiras. Rev. Mus. Paulista, São Paulo, 6: 482-487.

WHEELER, Q.D. 1985. Larval characteres of a neotropical Socotcryptus (Coleoptera: Leiodidae), a nest associate of stingless bees (Hymenoptera: Apidae). Jour. N.Y. Entomol. Soc. 93: 1082-1083.

WILSON, E. O. 1971. The insects societies. Massachusetts, Harvard Univ. Press, 548p.

YANEGA, D. \& R.A.B. LESCHER. 1994. Beetles associated with bee nests (Hymenoptera: Apidae) in Chiapas, México, with descriptions of the immatures stages of Vanonus balteatus Wernner (Coleoptera: Aderidae, Eudomychidae, Meloidae). Coleopterists Bull. 48: 355-360.

Recebido em 29.IV.1999; aceito em 08.II.2000. 